\title{
(n)
}

\section{Headache and Meningismus Following Lumbar Puncture}

\author{
Lomber Ponksiyon Sonrası Gelișen Bașag̃rısı ve Meningismus
}

\author{
Fırat Bektaş, Secgin Söyüncü \\ Department of Emergency Medicine, Faculty of Medicine, Akdeniz University, Antalya, Turkey
}

\section{ABSTRACT}

Post-lumbar puncture headache is the most common complication of lumbar puncture. This condition is thought to be the result of persistent cerebrospinal fluid leakage at the puncture site, leading to low cerebrospinal fluid pressure and traction on the meninges and intracranial veins. Associated symptoms may include nausea, vomiting, auditory and vestibular symptoms. Meningeal irritation signs are unexpected as clinical findings unless serious medical conditions such as subarachnoid hemorrhage or meningitis occur. We are present a case of headache and meningismus following by lumbar puncture. A 17-year-old female presented to the emergency department suffering from headache, nausea and vomiting, starting one day after a lumbar puncture procedure. The characteristics of the headache were different and more severe than the previous form. Her vital signs and physical and detailed neurological examination were normal, except meningismus findings such as neck stiffness and Brudzinksy's sign. Since the meningismus findings were unexpected, lumbar puncture was performed again to diagnose meningitis and subarachnoid hemorrhage. Cerebrospinal fluid pressure, protein, glucose, microscopic examination, blood and cerebrospinal fluid cultures were normal. Finally, magnetic resonance imaging of the brain revealed no pathological meningeal enhancement. In patients harboring uncontrollable factors, variables such as needle size, bevel orientation and the avoidance of traumatic lumbar puncture should be taken into consideration more seriously than ever. Furthermore, since, meningeal irritation signs such as neck stiffness and Brudzinksy's and Kernig's signs are not the expected clinical findings of post-lumbar puncture headache, serious medical conditions such as subarachnoid hemorrhage and meningeal infections should be investigated in the emergency setting.

Keywords: Headache, meningismus, lumbar puncture Received: 18.07.2011 Accepted: 05.10.2011

\section{ÖZET}

Lomber ponksiyon sonrası en sık görülen komplikasyon baș ag̃rısıdır. Bu durumun persistant ig̃ne giriş yerinde ortaya çıkan persistant beyin omurilik sıvı kaçag̃ına ve beyin omurilik sıvı basıncının düșmesine ve meningeal ve kafa içi venlerin traksiyonu sonucu oldug̃u düșünülmektedir. Buna bag̃lı olarak bulantı, kusma ve vestibüler belirtiler ortaya çıkabilir. Meningeal irritasyon bulguları sunaraknoid kanama veya menenjit olmadıg̃ı sürece beklenmeyen klinik bulgulardır. Lomber ponksiyon sonrası ortaya çıkan bașag̃rısı ve meningismus ile prezente olan bir olgu sumunu yaptık. Onyedi yașında bayan hasta lomber pnksiyon yapıldıktan bir gün sonar ortaya çıkan baș ag̃rı, bulantı ve kusma șikayeti ile acil servise getirildi. Hastanın yașamsal bulguları, fiziksel ve detaylı nörolojik muayenesi ense sertlig̃i ve Brudziski bulgusu varlıg̃ı dıșında normaldi. Bu bulgular olması nedeniyle menenjit veya sunaraknoid kanama tanısını araștırmak için lomber ponksiyon tekrarlandı. Beyin omurilik sıvı basıncı, protein, glukoz ve mikroskobik muayene ile kan ve beyin omurilik sıvı kültürleri normaldi. Son olarak yapılan manyetik rezonans görüntüleme teknig̃i ile meningeal tutulum araștırması da normaldi. Bu hastalardaki control edilmeyen ig̃ne boyutu, hasta oryantasyonu, travmatilk lomber ponksiyondan kaçınma gibi nedenler çok dajha ciddi sonuçlar ortaya çıkarabilir. Ense sertlig̃i, brudziski, kernig bulgusu gibi meningeal irritasyon bulguları lomber ponksiyon sonrası beklenmeyen fizik muayene bulgularıdır. Bu hastalarda mutlaka sunaraknoidal kanama ve meningeal infeksiyonların varlıg̃ı mutlaka araștırılmalıdır.

Anahtar Kelimeler: Baș ag̃rısı, meningismus, lomber ponksiyon Geliş Tarihi: 18.07.2011 Kabul Tarihi: 05.10.2011 


\section{Introduction}

Post-lumbar puncture headache (PLPHA) is the most common complication of lumbar puncture (LP). This condition is thought to be the result of persistent cerebrospinal fluid leakage at the puncture site, leading to low cerebrospinal fluid (CSF) pressure and traction on the meninges and intracranial veins. The incidence of PLPHA has been reported to be from 1 to $70 \%$ since several risk factors influence its development $(1,2)$. Furthermore, meningismus evoked by lumbar puncture has not been reported in the medical literature, except for an article describing subarachnoid hemorrhage (SAH) after LP (3).

\section{Case Report}

A 17-year-old female presented to the emergency department (ED) suffering from headache, nausea and vomiting, which had started one hour previous. Her complaint started suddenly as a severe sharp pain, located predominantly in her right hemicranium, and increased gradually. She had no medical history and was not taking any medications. Her vital signs and physical and detailed neurological examination were normal. After intravenous administration of a non-steroidal anti-inflammatory drug and metoclopramide, computerized tomography $(\mathrm{CT})$ of the brain was performed in order to rule out SAH and any other pathological conditions. Because the brain CT was negative, we performed LP due to the possibility of CT-negative SAH using a 22 gauge needle. The evaluation of her CSF revealed no pathological findings. After analgesic treatment and observation, the cessation of her complaints was achieved and she was discharged from the ED, fully recovered.

Two days later, she came back to the ED with the same complaint. Her symptoms had started one day after the procedure. The characteristics of the headache were different and more severe than the previous form. Her headache was located in the occipital area and was throbbing in character. Her headache improved in the supine position. There were no local infection signs such as cellulites or abscesses around the procedural area. Her vital signs and physical and detailed neurological examination were normal, except for meningismus findings such as neck stiffness and Brudzinksy's sign. As the meningismus findings were unexpected, LP was performed again to look for meningitis or SAH. CSF pressure, protein, glucose, microscopic examination, blood and CSF cultures were normal. Finally, magnetic resonance imaging of the brain revealed no pathological meningeal enhancement (Figure 1). The patient was discharged from the ED, fully recovered.

\section{Discussion}

$L P$ is an ED procedure which is often performed to obtain information on the CSF fluid to aid in the diagnosis of medical emergencies such as meningitis, encephalitis and SAH. A number of complications such as cerebral herniation, infection at the puncture site, hemorrhage resulting from traumatic taps and neuropathies involving cranial nerves III, IV, V, VI, VII and VIII have been reported. PLPHA is the most common complication of a LP. The reported incidence range is $2-40 \%$ and is higher after diagnostic LP than for epidural anesthesia $(1,4,5)$. Post-LP headache occurs when the patient is erect and is completely or partially relieved when recumbent. The pain

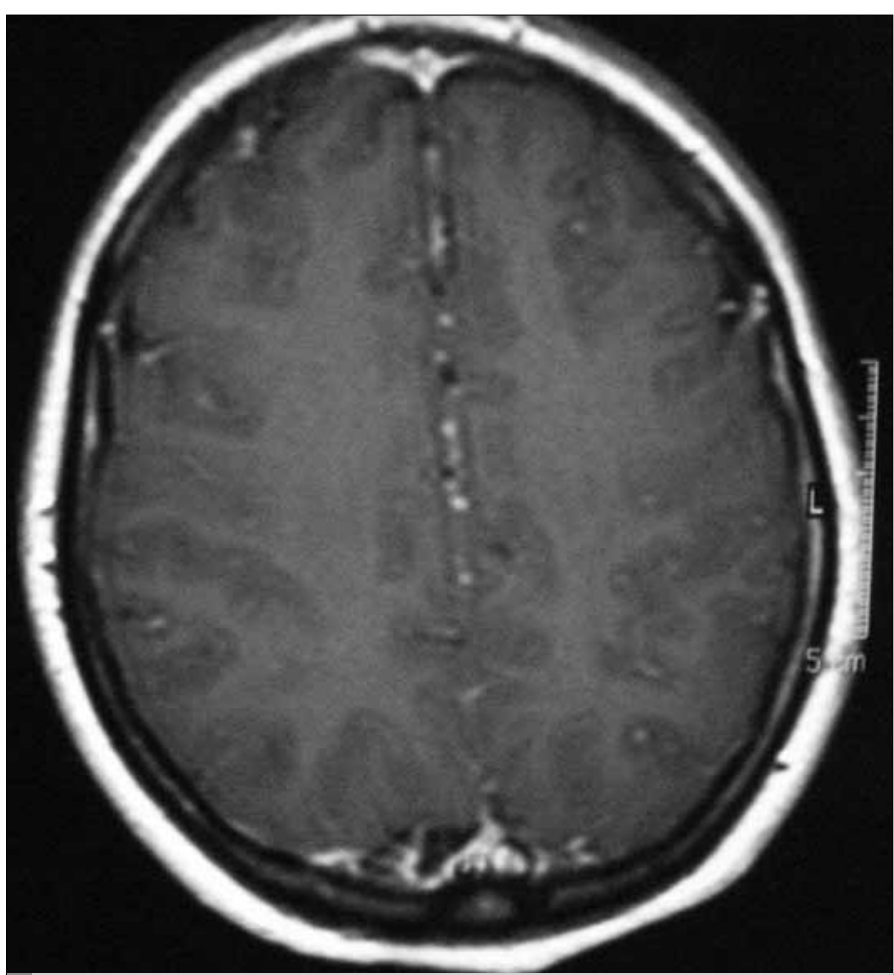

Figure 1. Post-contrast T1-weighted MR images show no abnormal enhancement

can start 24-48 hours after the procedure and generally lasts one or two days, but could be delayed up to 12 days (6). There are also reports of a duration of months and even more than one year $(7,8)$.

PLPHA is thought to be due to continued CSF leakage through the hole in the dura, which reduces the CSF cushion of the brain. In the upright position, the pull of gravity on the brain produces traction of the blood vessels and any structures tethering the brain to the pain-sensitive dura (9). Associated symptoms may include nausea, vomiting, auditory and vestibular symptoms. Meningeal irritation signs such as neck stiffness and Brudzinksy's and Kernig's signs may be expected as clinical findings, as is the case with serious medical conditions such as SAH and meningeal infections.

PLPHA is related to a number of factors, including young age, female gender, headache history, small body mass index and pregnancy (10). Despite these uncontrollable factors, there are also some variables which can influence the incidence of PLPHA such as needle size (should be less than 20 gauge), bevel orientation and the number of dural punctures (11-13). The position of the patient after LP, the volume of fluid removed during LP and hydration following LP have all been found to affect the incidence of PLPHA $(10,13,14)$.

\section{Conclusion}

Our patient was a young female with a small body mass index and we performed two LPs, which were traumatic, with large (22 gauge) needles. Our patient's PLPHA probably occurred due to these factors. In patients harboring uncontrollable factors, variables such as needle size, bevel orientation and the avoidance of traumatic LP 
should be taken into consideration more seriously than ever. Furthermore, since, meningeal irritation signs such as neck stiffness and Brudzinksy's and Kernig's signs are not the expected clinical findings of PLPHA, serious medical conditions such as SAH and meningeal infections should be investigated in the emergency setting.

\section{Conflict of interest}

No conflict of interest was declared by the authors.

\section{References}

1. Leibold RA, Yealy DM, Coppola M, Cantees KK. Post-dural-puncture headache: characteristics, management, and prevention. Ann Emerg Med 1993; 22: 1863-70. [CrossRef]

2. Sudlow C, Warlow C. Posture and fluids for preventing post-dural puncture headache. Cochrane Database Syst Rev 2001; 2: CD001790.

3. Sicuteri F. Headache and meningismus evoked by lumbar puncture and subarachnoid hemorrhage: a biochemical interpretation. Headache 1966; 5: 108-10. [CrossRef]

4. Vilming ST, Kloster R. Post-lumbar puncture headache: clinical features and suggestions for diagnostic criteria. Cephalalgia 1997; 17: 778-84. [CrossRef]

5. Fong B, VanBendegon JM. Lumbar Puncture. In: Reichman EF, Simon RR eds. Emergency Medicine Procedure. NewYork: McGraw Hill: 859-80.
6. Ahmed SV, Jayawarna C, Jude E. Post lumbar puncture headache: diagnosis and management. Postgrad Med J 2006; 82: 713-6. [CrossRef]

7. Seebacher J, Ribeiro V, LeGuillou JL, Lacomblez L, Henry M, Thorman F, et al. Epidural blood patch in the treatment of post dural puncture head ache : a double blind study. Headache 1989; 29: 630-2. [CrossRef]

8. Lance JW, Branch GB. Persistent headache after lumbar puncture. Lancet 1994; 343: 414. [CrossRef]

9. Gass H, Goldstein AS, Ruskin R, Leopold NA. Chronic postmyelogram headache. Isotopic demonstration of dural leak and surgical cure. Arch Neurol 1971; 25: 168-70. [CrossRef]

10. Evans RW, Armon C, Frohman EM, Goodin DS. Assessment: prevention of post-lumbar puncture headaches: report of the therapeutics and technology assessment subcommittee of the american academy of neurology. Neurology 2000; 55: 909-14. [CrossRef]

11. Tourtellotte WW, Henderson WG, Tucker RP, Gilland O, Walker JE, Kokman E. A randomized, double blind clinical trial comparing the 22 versus 26 gauge needle in the production of the post-lumbar puncture syndrome in normal individuals. Headache 1972; 12: 73-8. [CrossRef]

12. Mihic DN. Postspinal headache and relationship of needle bevel to longitudinal dural fibers. Reg Anesth 1985; 10: 76-81.

13. Hilton-Jones D, Harrad RA, Gill MW, Warlow CP. Failure of postural maneuvers to prevent lumbar puncture headache. J Neurol Neurosurg Psychiatry 1982; 45: 743-6. [CrossRef]

14. Carbaat PA, van Crevel H. Lumbar puncture headache: Controlled study on the preventative effect of 24 hours bed rest. Lancet 1981; 1:1133-5. [CrossRef] 